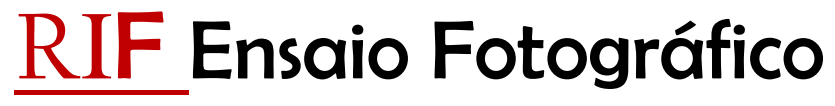

\section{Casa e rua se encontram na Festa do Divino}

Rafael Schoenherr ${ }^{1}$

A Festa do Divino remete a uma larga tradição do entrecruzamento entre a cultura popular e o âmbito religioso ainda presente em diversas cidades brasileiras. Processos de conservação e de transformação cultural se atualizam no âmbito local e expressam a particularidade que a festividade vai assumir em cada situação, comunidade ou época. 0 evento 'festa' pode ser entendido como prática comunicacional - agregadora de marcas, expressões, gestos - implicada no religioso, no popular e no urbano.

O ensaio fotográfico a seguir registra cenas da Festa do Divino que aconteceu no dia 15 de maio de 2016, em Ponta Grossa (PR). As imagens foram produzidas por três estudantes do curso de Jornalismo da Universidade Estadual de Ponta Grossa (UEPG) - Saori Honorato, Angelo Rocha e André da Luz -, inseridos no projeto de extensão Lente Quente, responsável por desenvolver cobertura dos acontecimentos da cultura e contribuir, assim, para a memória das manifestações culturais da cidade por meio de um acervo fotográfico online (disponível em www.flickr.com/lentequente) que já ultrapassa a marca das duas mil fotografias catalogadas.

As origens do culto ao Divino Espírito Santo remetem a Portugal, no século XIII, quando diante da crise do país a Rainha Isabel de Aragão fez uma promessa. Como agradecimento, realizou um festejo popular. No Brasil, tal prática teria chegado por volta do século XVIII, primeiramente nos litorais de Santa Catarina e Rio Grande do Sul. A partir daí, o rito se espalha pelo país, demarcando territorialidades e espaços sagrados específicos, conforme cada universo identitário de referência.

Uma das singularidades do culto ao Divino em Ponta Grossa está na sua organização material a partir de um lugar, a Casa do Divino, localizada na Rua Santos Dumont, número 524, na região central, construída em 1840: “(...) a Casa do Divino estabelecida em Ponta Grossa é a única no Brasil que existe como um local de culto, em um imóvel específico e que está aberto durante todo o ano desenvolvendo diferentes atividades religiosas, além da Festa ao Divino Espírito Santo (...)" (JOHANSEN, 2015, p. 7).

\footnotetext{
${ }^{1}$ Doutorando em Gestão do Território pela Universidade Estadual de Ponta Grossa. Jornalista, professor do curso de Jornalismo da UEPG. Coordenador do projeto de extensão em fotojornalismo cultural, Lente Quente (rafaelschoenherr@gmail.com)
} 


\section{RIF, Ponta Grossa/ PR Volume 14, Número 33, p.144-155, set./dez. 2016}

Isso significa que existe um ponto predial, uma espécie de marco territorial centralizador das atividades de crença, visitas, rezas, promessas, devoção. Sendo que nos momentos festivos, sobretudo no domingo de Pentecostes (50 dias após a Páscoa), essa área se vê expandida para as ruas. É quando a crença extrapola as paredes da casa e ganha contornos de festejo, de procissão e de missa na igreja. Nessa ocasião, modifica-se a área de abrangência, por assim dizer, da manifestação cultural - ela se torna visível na rua.

As origens da Casa do Divino em Ponta Grossa remetem a episódio ocorrido com D. Maria Julia Cesarino Xavier, que, aos 60 anos, apresentava problemas de memória. Ao viajar para Castro, passando pela atual cidade de Carambeí, perdeu-se sem conseguir descobrir o caminho para retornar a Ponta Grossa. Foi quando parou para beber água em um olho d'água e viu a imagem do Divino Espírito Santo gravada em um pedaço de madeira submerso. Após ter encontrado a imagem, D. Maria tocou-a e, de joelhos, rezou fervorosamente - em seguida, sentiu-se curada dos problemas de memória. Assim conseguiu voltar para Ponta Grossa. "A notícia de sua cura se espalhou entre amigos e familiares". (ROCHA, 2015)

Aos poucos, a casa passa a funcionar como espaço de sociabilidade e manifestação religiosa, que se desdobra também em procissão. "Amigos e familiares começaram a frequentar o local, onde eram realizadas novenas, rezas, procissões com as bandeiras até as residências próximas, culminando com a festa em honra ao Divino Espírito Santo no domingo de Pentecostes." (JOHANSEN, 2015, p. 3)

Os devotos não apenas visitam a Casa do Divino e ali fazem orações, como deixam "cartas, bilhetes com pedidos ou agradecimentos escritos, fotografias com e sem dedicatória, ex-votos, quadros de santos que compõem até hoje o acervo da casa." (JOHANSEN, 2015, p. 34)

Tanto Rocha (2015) quanto Johansen (2015) ressaltam que o culto ao Divino em Ponta Grossa se consolida a um só tempo como patrimônio material e imaterial, ao mobilizar o concreto e o simbólico no fenômeno popular religioso. E é justamente a festa um dos acontecimentos que presentifica essa dimensão imaterial que irrompe na cena urbana em data específica. As fotografias a seguir buscam flagrar parcelas desse momento de atualização do patrimônio cultural local.

Os patrimônios culturais imateriais da Casa do Divino são o saber e o modo de fazer as: novenas, procissões, rezas, os cantos e a festa em honra ao Divino Espírito Santo, patrimônios esses que assim como o patrimônio material devem ser preservados, pois remetem a memória dessa cultura religiosa. Assim, com a preservação tanto do patrimônio material, quanto do imaterial, da referida casa também está se preservando a história e a memória da sociedade ponta-

145 | Casa e rua se encontram na Festa do Divino 


\section{RIF, Ponta Grossa/ PR Volume 14, Número 33, p.144-155, set./dez. 2016}

grossense, passando a se tornar um dos elementos de identificação cultural dessa comunidade. (ROCHA, 2015)

A Festa do Divino em Ponta Grossa como prática comunicacional ampla da cultura popular rearranja a casa e a rua, a festa popular e a religiosidade, o material e o simbólico. Entende-se que nessa transposição da casa para a rua em dia de festa reside um ponto singular para apreensão das manifestações folkcomunicacionais da cultura urbana.

No cruzamento dessas 'geografias' está o ato fotográfico, calcado na ação individual do fotógrafo, da singularidade do olhar e do percurso, mas também orientado pela particularidade do acontecimento e em diálogo com as referências e tensões abrangentes de produção de sentidos, os códigos (da religião, da cultura popular, da cultura urbana, do artístico, do lúdico, do jornalístico...). As fotografias transitam entre o material e o simbólico. Primeiro, pelo percurso do fotógrafo em campo. Em seguida, na trajetória do olhar sobre as fotografias produzidas.

Em hipótese, a comunicação surge aí como espaço de enlace, de envolvimento entre o patrimônio cultural e imaterial, entre a Casa do Divino e o festejo, o rito, a festa que atualiza a crença. O desafio é se entender como tais manifestações culturais se particularizam e assumem feições locais em cada situação, festejo, momento específico e situado de celebração.

Por meio das legendas fotográficas a seguir, pretende-se interpretar as fotografias (produzidas em outro contexto) a partir do enquadramento oferecido por Rocha (2015) e Johansen (2015) e em diálogo com o pensamento folkcomunicacional. Uma tentativa de colocar em contato ideias advindas da história, da comunicação e da geografia para melhor reconhecer a singularidade das manifestações culturais, tal como a Festa do Divino.

146 | Casa e rua se encontram na Festa do Divino 
RIF, Ponta Grossa/ PR Volume 14, Número 33, p.144-155, set./dez. 2016

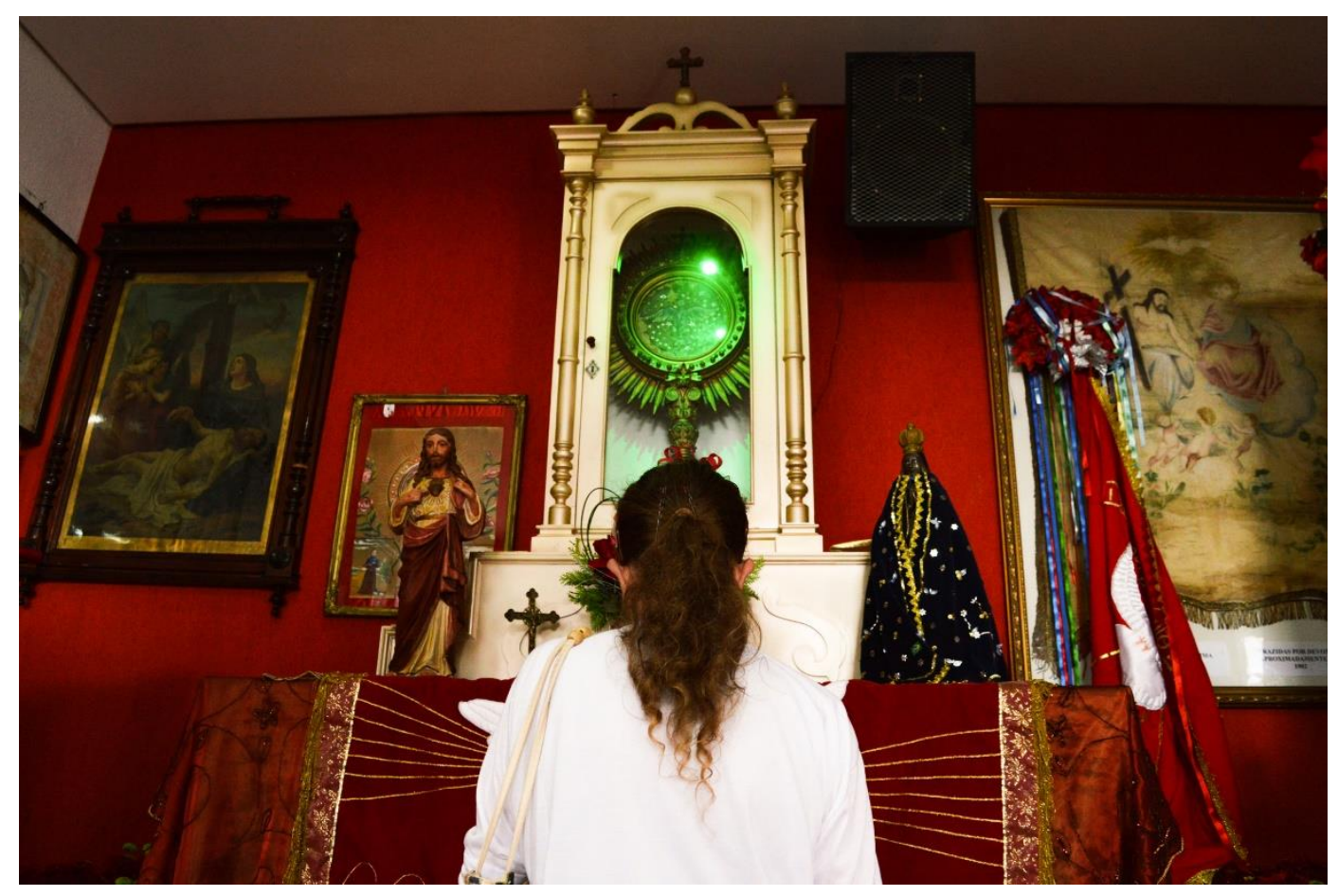

Figura 1: A Casa do Divino, em Ponta Grossa, foi tombada pelo Conselho Municipal de Patrimônio Cultural em 4 de agosto de 2006, considerada presença importante na paisagem da cidade, contemplando os conceitos de patrimônio tangível e intangível. O parecer de tombamento reconhece que a Casa do Divino possui: "valor arquitetônico, histórico e referencial como lugar de memória, e como patrimônio cultural intangível, é muito presente na residência construída na Rua Santos Dumont, 524'” (ROCHA, 2015). O local está aberto há mais de 130 anos e "mantém-se enquanto um espaço de religiosidade católica popular, que possui materialidade específica em um local único (...)" (JOHANSEN, 2015, p. 4). Fotografia de Saori Honorato. 
RIF, Ponta Grossa/ PR Volume 14, Número 33, p.144-155, set./dez. 2016

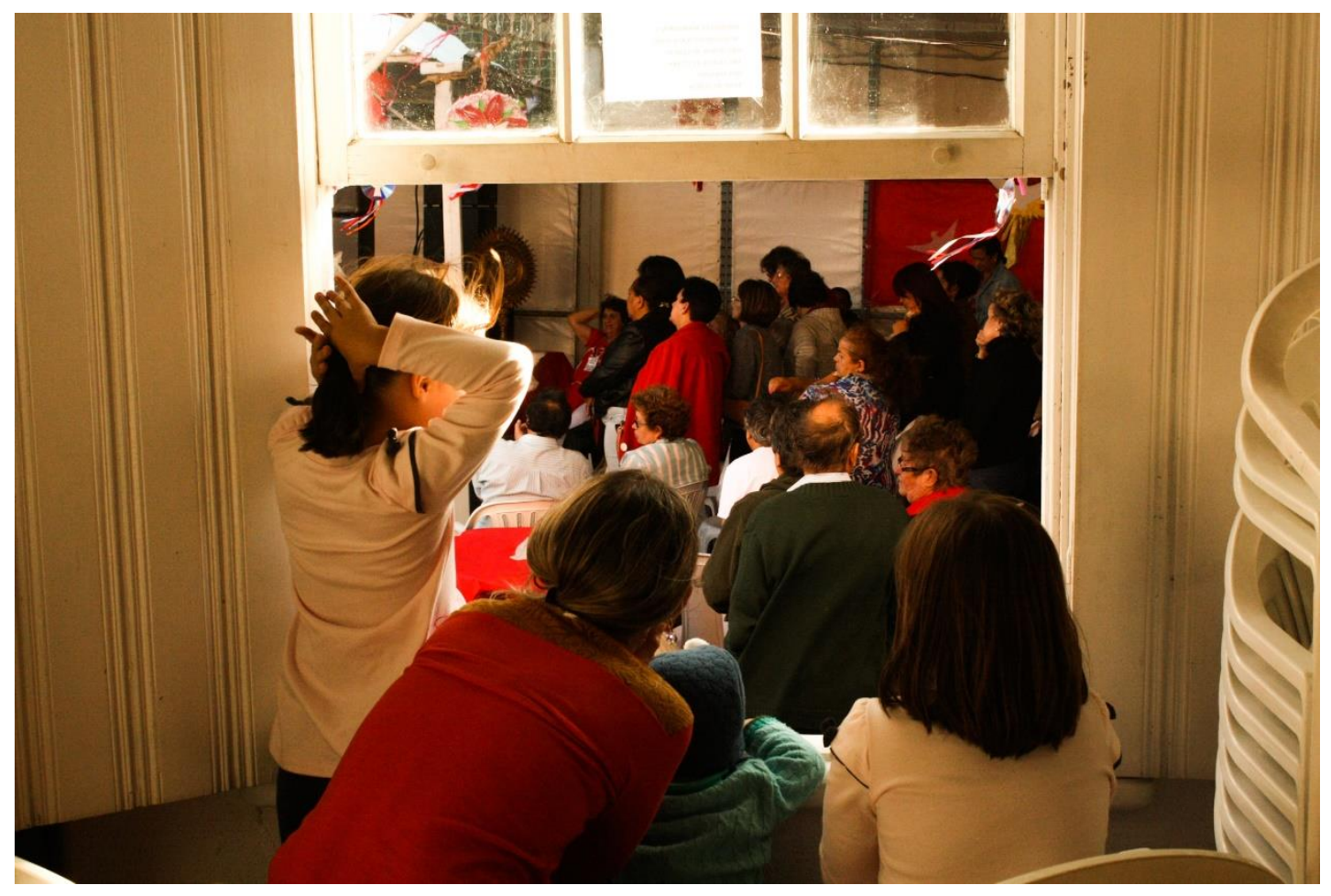

Figura 2: Estima-se que a Casa do Divino, em Ponta Grossa, receba de 30 a 50 pessoas por dia. 0 público aumenta durante a Festa do Divino em 15 de maio. De acordo com Rocha (2015), é nesse espaço que os fiéis legitimam sua comunidade, ao mesmo tempo em que buscam nessa edificação um "contato" com o mundo sagrado. "A 'Casa do Divino', portanto, passa a ser o 'elo' entre o devoto e o transcendente, tem a função de manter viva essa devoção na cidade, pois fortifica as relações sociais dos devotos, porque estando ali, reunidos, além de louvar o Divino, conversam, compram artigos devocionais e avigoram suas afinidades" (ROCHA, 2015). A Casa agrega pessoas de diferentes origens e perfis sociais, que passam assim a compartilhar um espaço, uma referência de identidade local - "não delimitada apenas pela lógica fixa dos territórios de naturalidade, mas dos territórios simbólicos" (JOHANSEN, 2015, p. 10). Fotografia de André da Luz. 


\section{RIF, Ponta Grossa/ PR Volume 14, Número 33, p.144-155, set./dez. 2016}

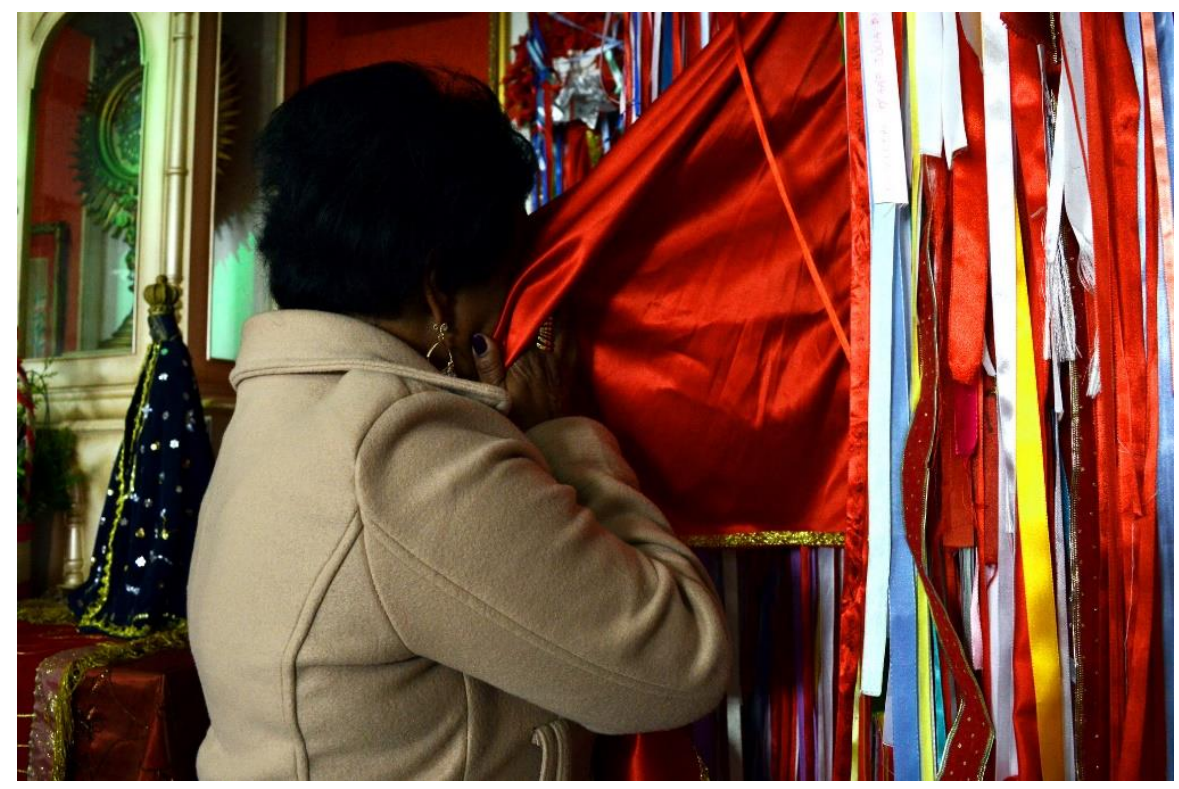

Figura 3: 0 símbolo de devoção da festa é uma bandeira vermelha com uma pomba branca no centro. É uma tradição os fiéis demonstrarem afeto aos objetos sagrados da celebração. Fotografia de Saori Honorato.

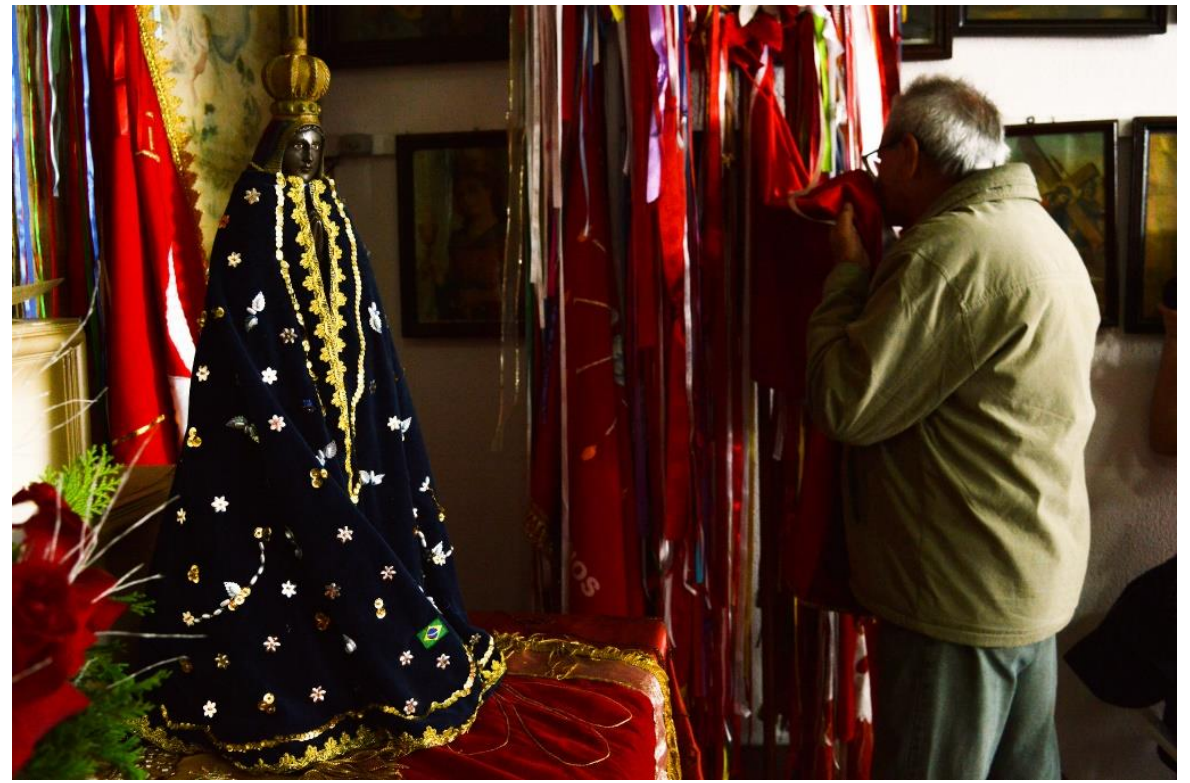

Figura 4: O acervo material da Casa do Divino $^{2}$ abriga um conjunto composto de: Imagem do Divino Espírito Santo encontrada em 1882, Bandeiras e Estandartes do Divino com mais de 120 anos, um acervo com mais de 14 mil fotos de devotos, aproximadamente 200 cartas datadas desde 1886, imagens de pedra sabão e mais de 100 quadros com imagens de santos, além de obras sacras. Fotografia de Saori Honorato. 
RIF, Ponta Grossa/ PR Volume 14, Número 33, p.144-155, set./dez. 2016

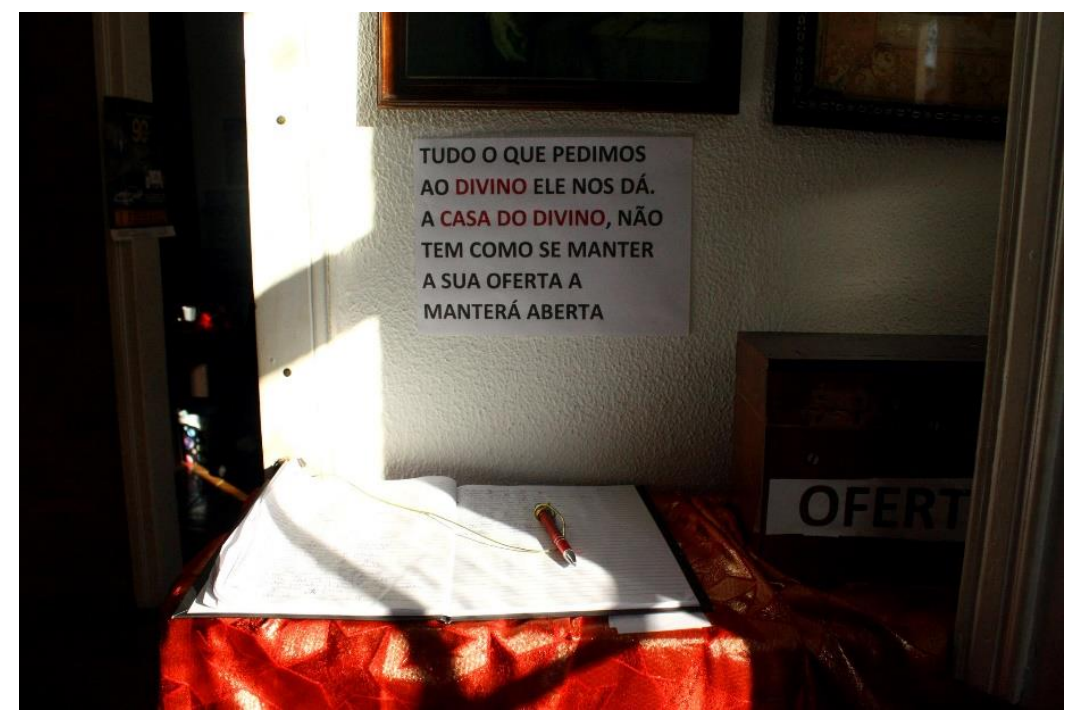

Figura 5: O tombamento da Casa do Divino como patrimônio não garante a manutenção do local, que depende de doações dos fiéis. A oferta se mistura às promessas e ao universo da crença. Fotografia de André da Luz.

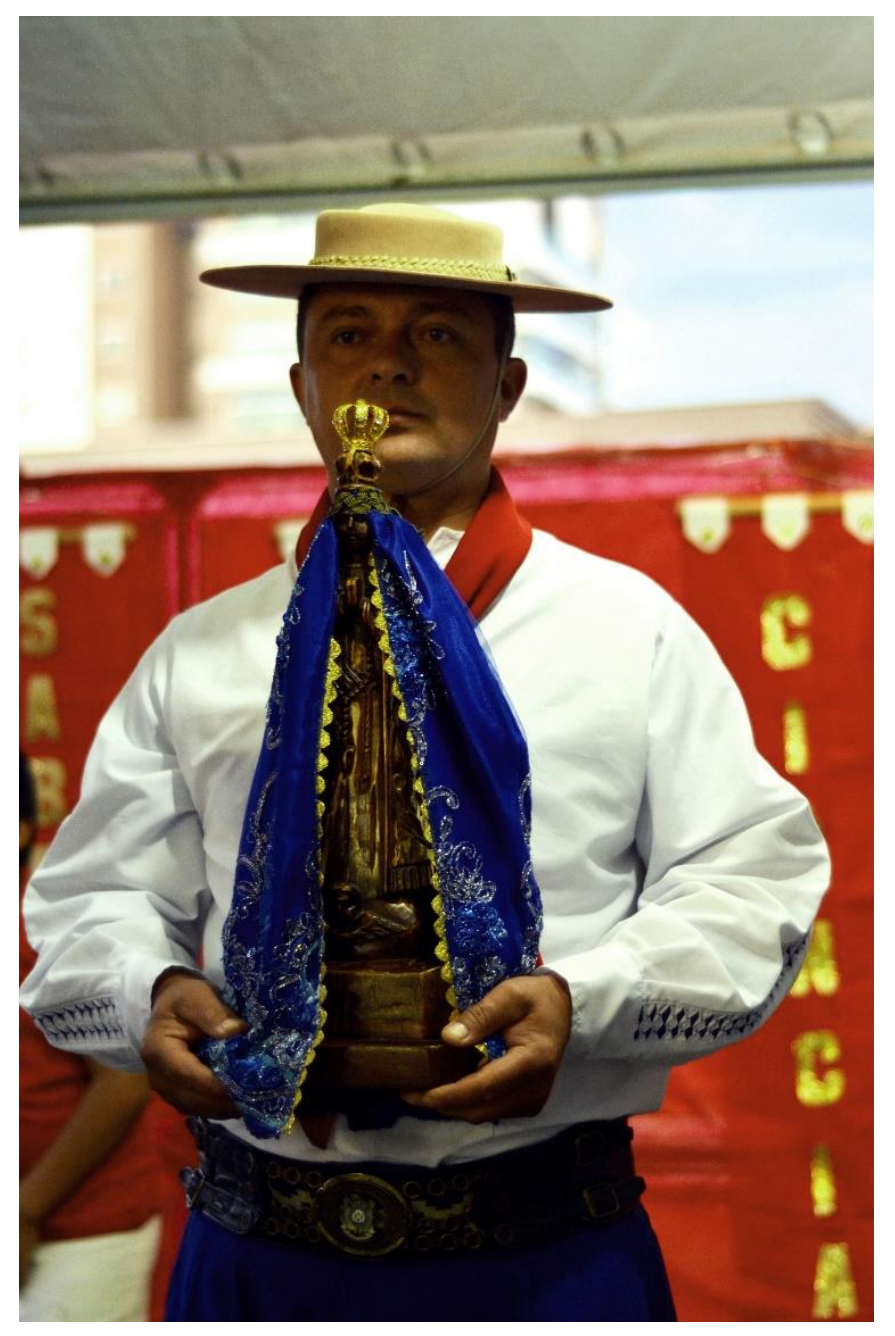

150 Casa e rua se encontram na Festa do Divino 


\section{RIF, Ponta Grossa/ PR Volume 14, Número 33, p.144-155, set./dez. 2016}

Figura 6 - Sincretismo na paisagem urbana. As referências ao Divino Espírito Santo compartilham o espaço com imagens ou demais alusões cristãs e católicas. Outra marca desse caráter híbrido da festa são grupos ou agremiações que participam da festa, trazendo adereços e símbolos particulares, como os centros de tradição gaúcha, que apresentam dança e música durante o festejo na rua em frente à Casa do Divino. Fotografia de Angelo Rocha.

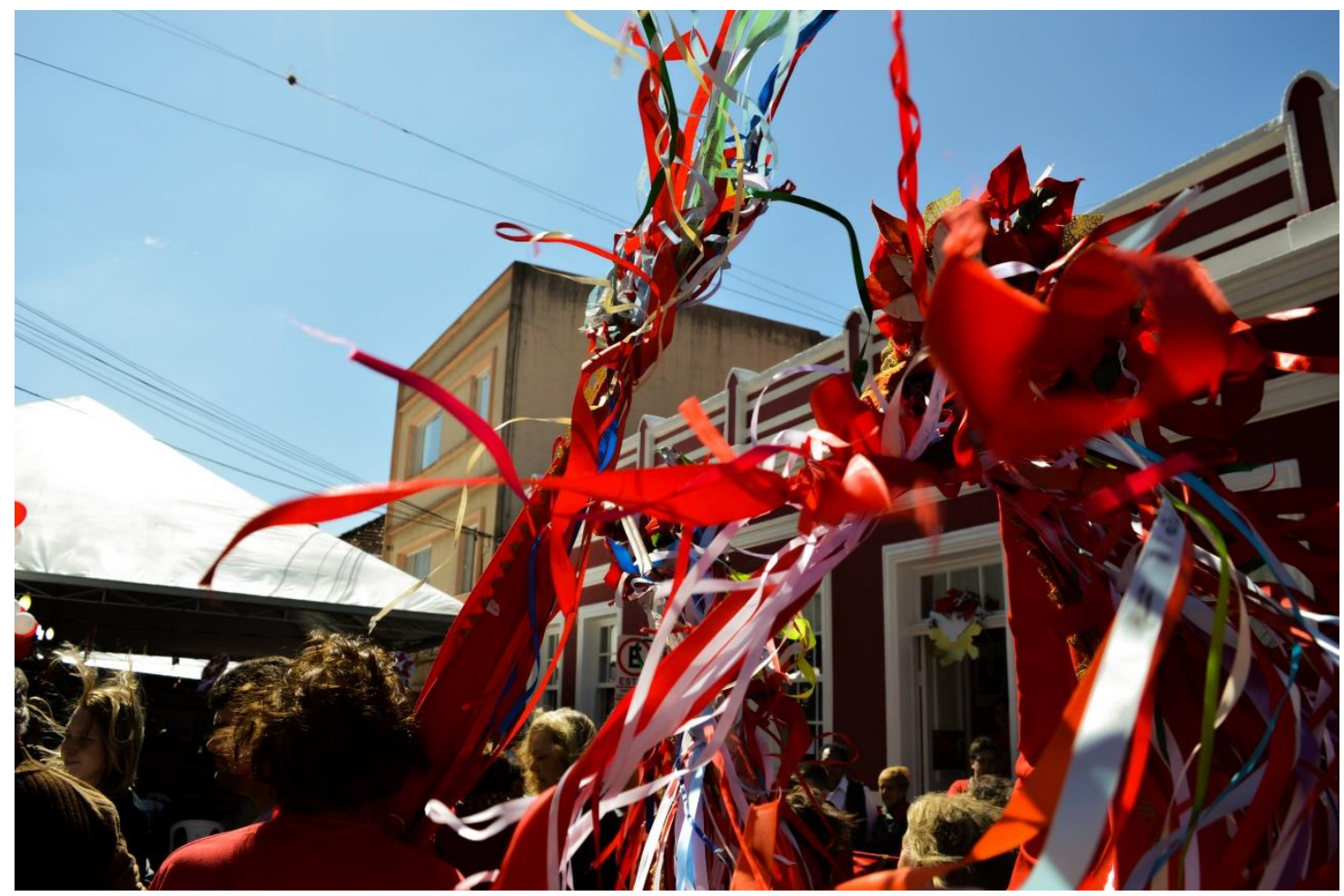

Figura 7 - Durante a Festa do Divino, a área da manifestação popular religiosa se expande, com barracas de lanche e apresentações culturais na Rua Santos Dumont, em frente ao prédio da Casa do Divino. O culto "extrapola a materialidade e a espacialidade da construção do imóvel" (JOHANSEN, 2015, p. 6). Bandeiras e fitas conferem um caráter lúdico a uma rua de pouco movimento aos domingos. De acordo com Lefebreve (1973, p. 137), o lúdico também deve ter espaço na cultura urbana, as ruas podem misturar o jogo e a informação, na luta humana contra a monotonia e o aborrecimento. A Festa do Divino marca um dos poucos momentos em que se fecha uma das ruas do centro de Ponta Grossa para uma celebração religiosa popular fora das igrejas ou dos desfiles cívicos. E possui uma dimensão bem mais 'localizada' do que a procissão de Corpus Christi. Está mais amarrada, por assim dizer, à ideia de lugar. Fotografia de Saori Honorato. 
RIF, Ponta Grossa/ PR Volume 14, Número 33, p.144-155, set./dez. 2016

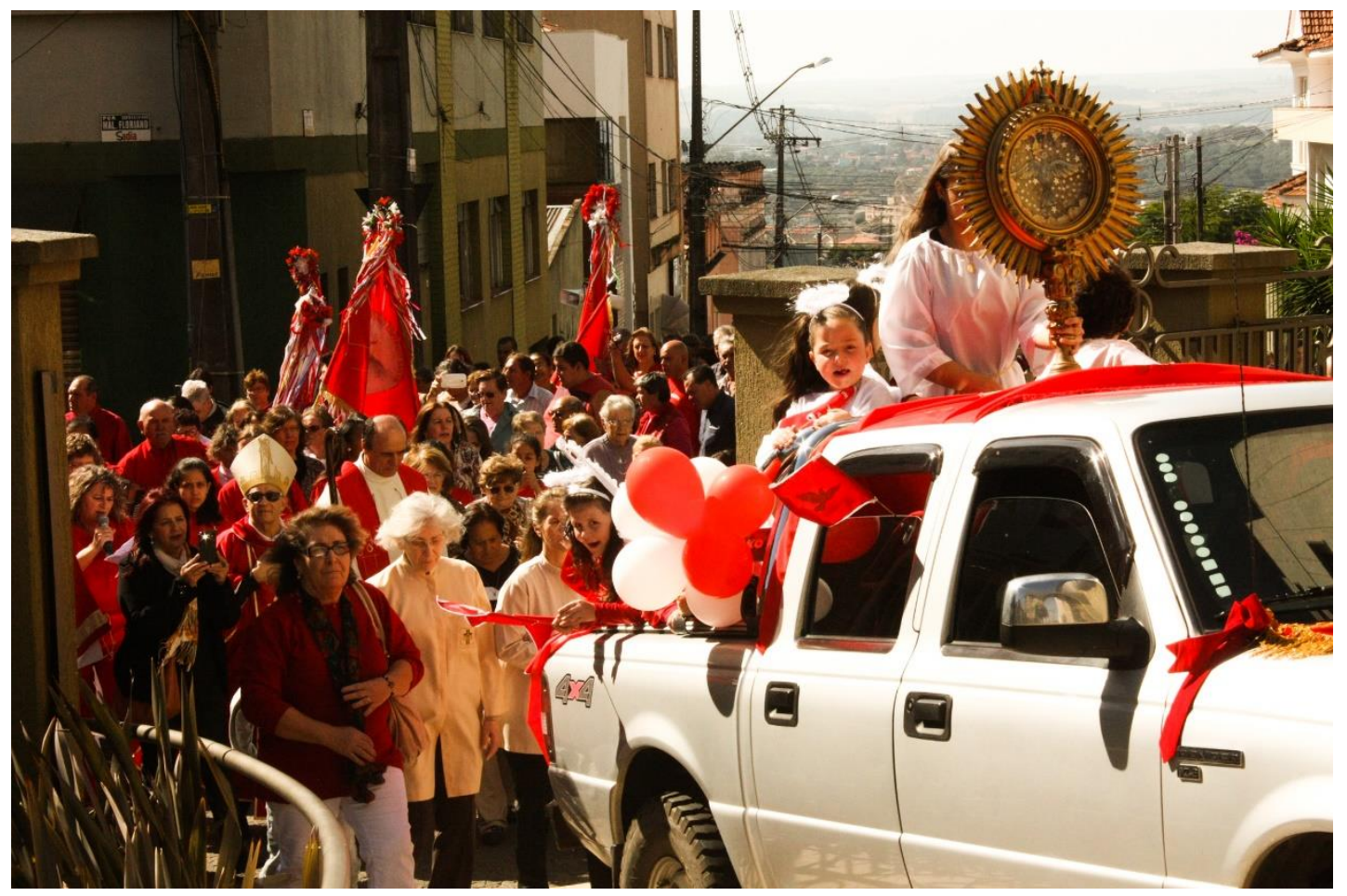

Figuras 8 e 9: Aproximadamente 5 mil pessoas presenciaram atividades culturais e religiosas, apresentações musicais, rodas de reza e procissão em direção à catedral Sant'Anna, encerrando com a celebração de uma missa especial realizada pelo Bispo Dom Sérgio Arthur Braschi. A procissão envolve poucas quadras do entorno da Casa do Divino, próxima à catedral. A procissão, por contraste ou complementação, demarca a paisagem urbana, compondo novos significados sobre tempo e espaço. Fotografias de André da Luz. 
RIF, Ponta Grossa/ PR Volume 14, Número 33, p.144-155, set./dez. 2016
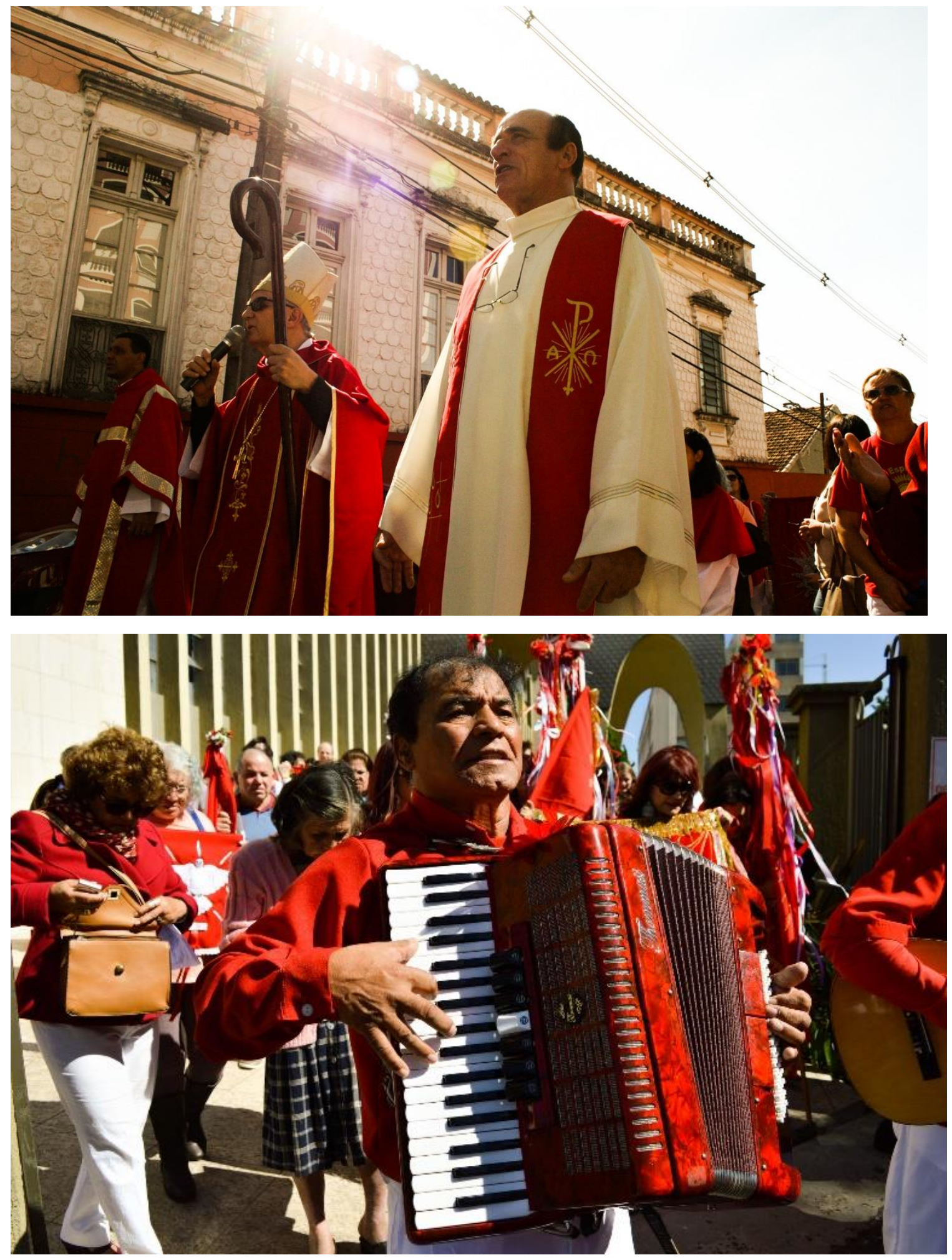

Figura 10 - Entre as manifestações comunicacionais populares presentes no rito de procissão está a música. Os fiéis aqui estão em frente ao prédio da catedral. Fotografia de Saori Honorato. 


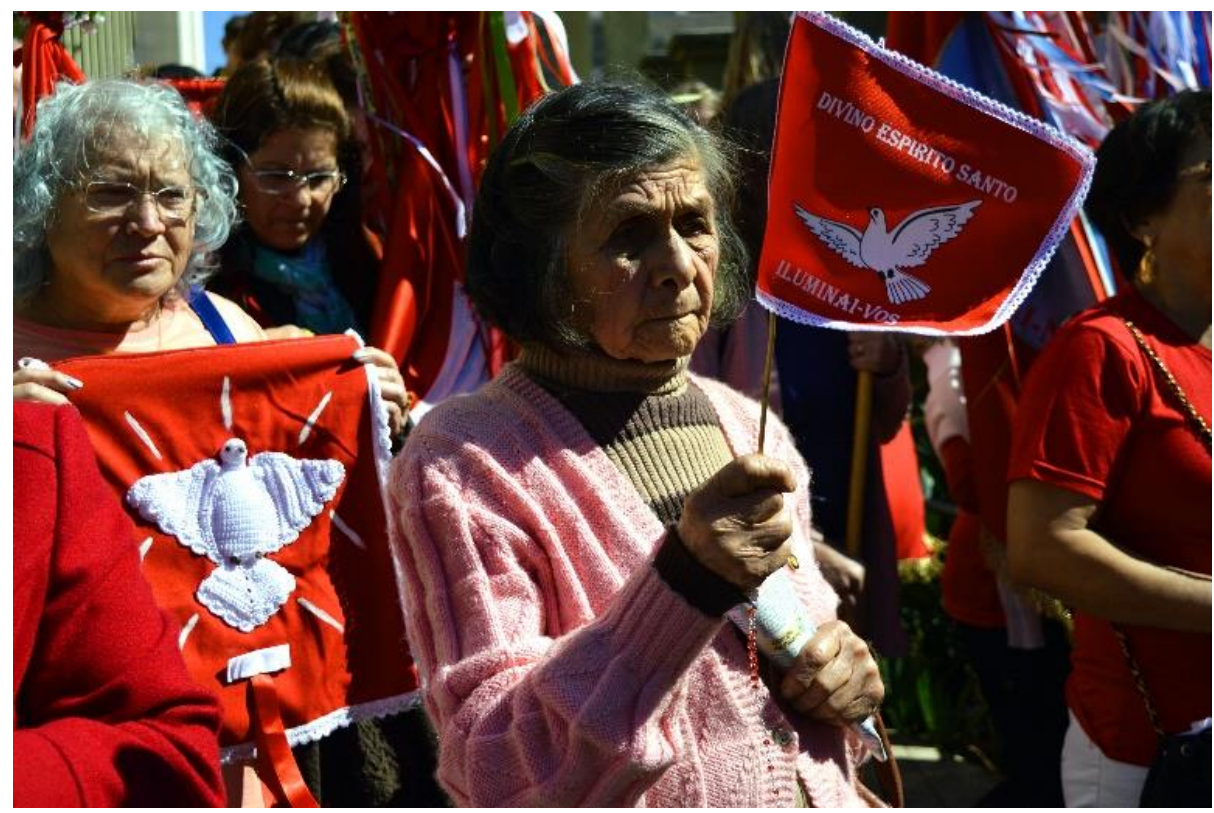

Figura 11: A marca visual mais forte da festa é a cor vermelha em bandeiras. A figura remete à imagem do Espírito Santo como pomba

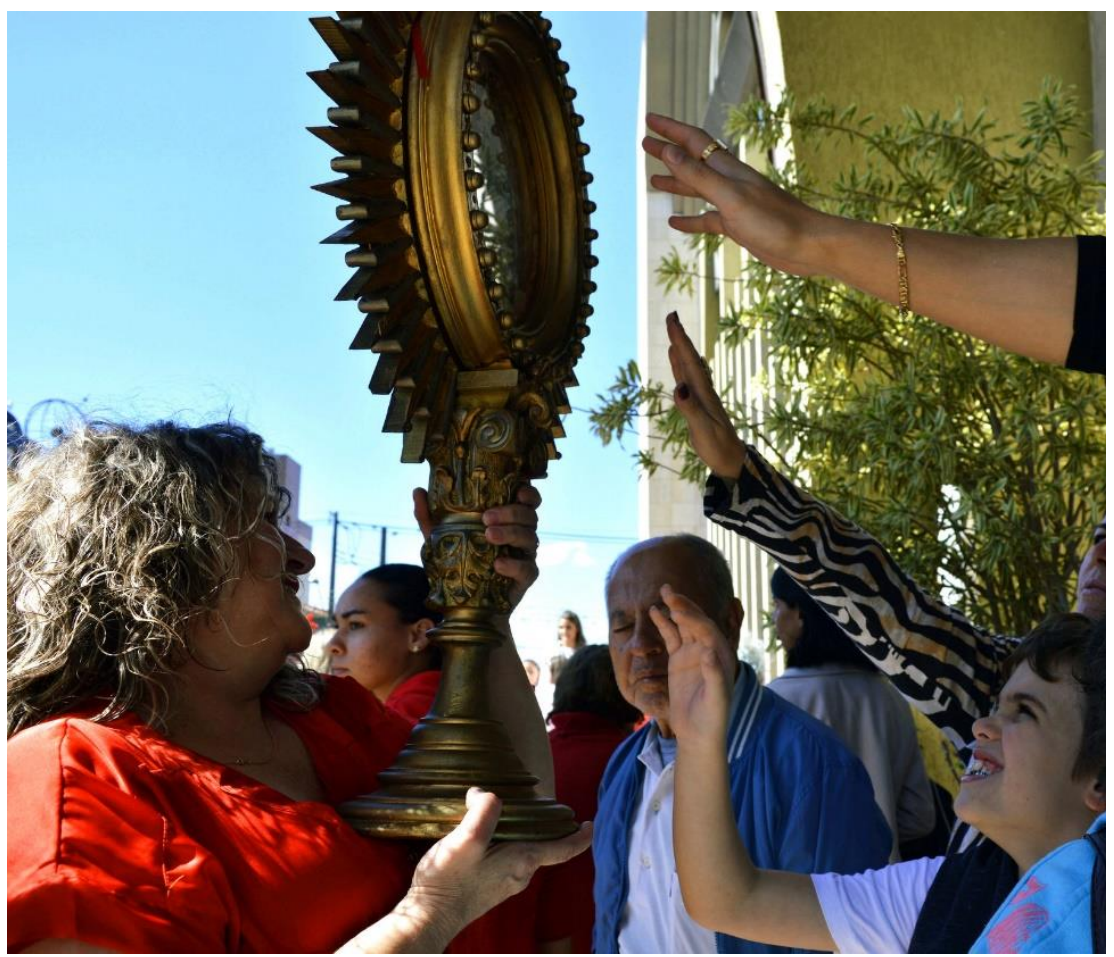

Figura 12 - 0 modo de fazer caracteriza o patrimônio imaterial (ROCHA, 2015). Entrada da procissão na catedral. Fotografia de Saori Honorato. 
RIF, Ponta Grossa/ PR Volume 14, Número 33, p.144-155, set./dez. 2016

Figura 13 - "Sendo assim, no transcurso de 132 anos de existência a Casa do Divino, personificada por suas representantes, desenvolveu atividades e ações buscando a delimitação e afirmação da crença no Divino Espírito Santo em uma área geográfica, talvez não pensada de forma consciente e específica, mas fundamental para sua existência e manutenção." (JOHANSEN, 2015, p. 8). Fotografia de André da Luz.

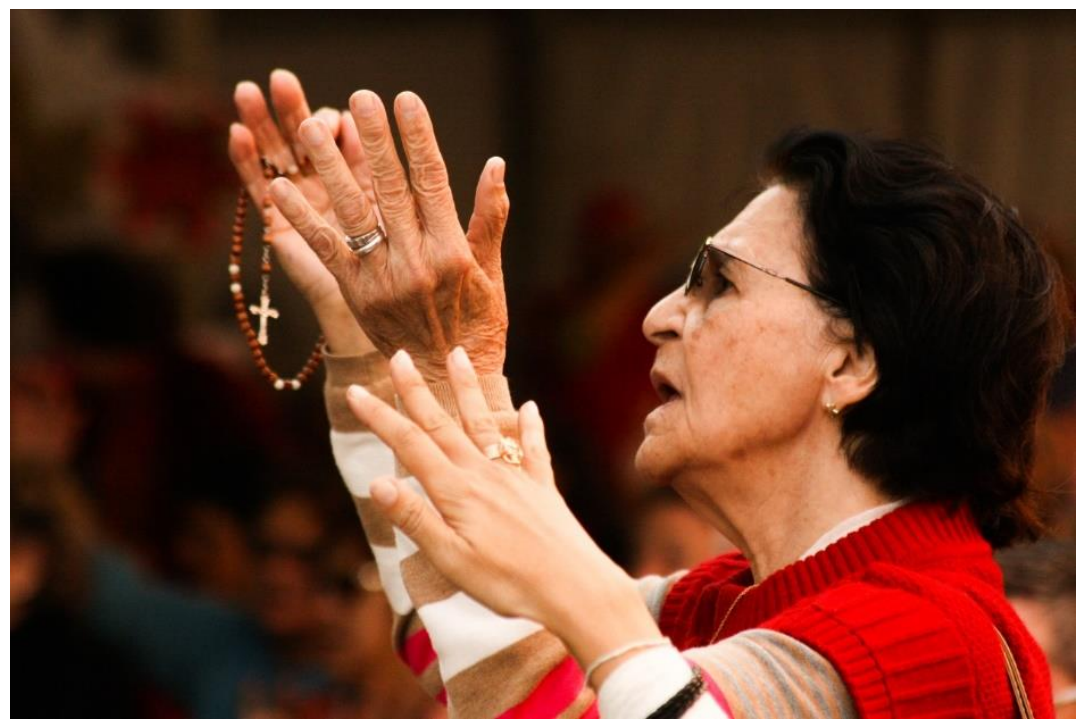

\section{Referências}

JOHANSEN, Elizabeth. Casa do Divino: a construção da territorialidade de um patrimônio cultural. II Congresso Internacional de História: UEPG-Unicentro, 2015. Disponível em: http://www.cih2015.eventos.dype.com.br/resources/anais/4/1429561709_ARQUIVO_IICongr essolnt.HistoriaUEPG.2015-textocompleto.pdf. Acesso em: 31 jul. 2016.

LEFEBVRE, Henri. De lo rural a lo urbano. Barcelona: Península, 1973.

ROCHA, Vanderley de Paula. Casa do Divino: patrimônio material e imaterial de Ponta Grossa. I Congresso de Patrimônio Cultural: patrimônio cultural e natural dos Campos Gerais, 2015. Disponível em: http://culturapg.com.br/periodicos/patrimonio/article/view/34/39. Acesso em: 31 jul. 2016. 